\title{
Repeated Swim Impairs Serotonin Clearance via a Corticosterone-Sensitive Mechanism: Organic Cation Transporter 3, the Smoking Gun
}

\author{
Nicole Baganz, ${ }^{1}$ Rebecca Horton, ${ }^{1}$ Kathryn Martin, ${ }^{3}$ Andrew Holmes, ${ }^{3}$ and Lynette C. Daws ${ }^{1,2}$ \\ Departments of ${ }^{1}$ Physiology and ${ }^{2}$ Pharmacology, University of Texas Health Science Center at San Antonio, San Antonio, Texas 78229, and ${ }^{3}$ Section on \\ Behavioral Science and Genetics, Laboratory for Integrative Neuroscience, National Institute on Alcoholism and Alcohol Abuse, National Institutes of \\ Health, Rockville, Maryland, 20852-9411
}

Activation of the hypothalamic-pituitary-adrenal (HPA) axis is associated with increased extracellular serotonin (5-HT) in limbic brain regions. The mechanism through which this occurs remains unclear. One way could be via HPA axis-dependent impairment of serotonin transporter (SERT) function, the high-affinity uptake mechanism for 5-HT. Consistent with this idea, we found that 5-HT clearance rate in hippocampus was dramatically reduced in mice exposed to repeated swim, a stimulus known to activate the HPA axis. However, this phenomenon also occurred in mice lacking SERT, ruling out SERT as a mechanism. The organic cation transporter 3 (OCT3) is emerging as an important regulator of brain 5-HT. Moreover, corticosterone, which is released upon HPA axis activation, blocks 5-HT uptake by OCT3. Repeated swim produced a persistent elevation in plasma corticosterone, and, consistent with prolonged blockade by corticosterone, we found that OCT3 expression and function were reduced in these mice. Importantly, this effect of repeated swim to reduce 5-HT clearance rate was corticosterone dependent, as evidenced by its absence in adrenalectomized mice, in which plasma corticosterone levels were essentially undetectable. Behaviorally, mice subjected to repeated swim spent less time immobile in the tail suspension test than control mice, but responded similarly to SERT- and norepinephrine transporter-selective antidepressants. Together, these results show that reduced 5-HT clearance following HPA axis activation is likely mediated, at least in part, by the corticosterone-sensitive 0CT3, and that drugs developed to selectively target OCT3 (unlike corticosterone) may be candidates for the development of novel antidepressant medications.

\section{Introduction}

A consistent observation from preclinical studies is that activation of the hypothalamic-pituitary-adrenal (HPA) axis raises levels of extracellular fluid (ECF) serotonin (5-HT) in various forebrain regions, including hippocampus-a critical neural locus for antidepressant medications (Campbell and Macqueen, 2004; Leonardo and Hen, 2006). This effect appears to generalize across different types of HPA axis activators, including exposure to aversive stimuli (Wilkinson et al., 1996; Amat et al., 1998; Linthorst et al., 2002; Hajós-Korcsok et al., 2003; Beekman et al., 2005), environmental enrichment (Brenes et al., 2008; Xu et al., 2009), and exercise (Meeusen and De Meirleir, 1995; GomezMerino et al., 2001). These increases are not always associated with activation of serotonergic dorsal raphe neurons innervating the forebrain or by increased 5-HT turnover and release (Lanfumey et al.,

\footnotetext{
Received May 27, 2010; revised Sept. 15, 2010; accepted Sept. 16, 2010.

This work was supported by National Institutes of Health Grant R01-MH64489 (L.C.D.), a National Alliance for Research on Schizophrenia and Depression Independent Investigator Award (L.C.D.), and National Institute on Alcohol Abuse and Alcoholism intramural research program (A.H.). We thank Drs. Randy Blakely, Ana Carneiro Georgianna Gould, Julie Hensler, Wouter Koek, and Glenn Toney for helpful discussions. We also thank Teri FrostoBurke, Jaclyn Munn, David Aguilar, and Steven Alvarado for excellent technical assistance.

Correspondence should be addressed to Lynette C. Daws, 7703 Floyd Curl Drive, MC 7756, San Antonio, TX 78229. E-mail: daws@uthscsa.edu.

D0I:10.1523/JNEUROSCI.2740-10.2010

Copyright $\odot 2010$ the authors $\quad 0270-6474 / 10 / 3015185-11 \$ 15.00 / 0$
}

2008), suggesting involvement of mechanisms regulating ECF levels of 5-HT after release.

The serotonin transporter (SERT) is the principle highaffinity, low-capacity uptake mechanism responsible for clearing released 5-HT from the extracellular space (Blakely et al., 1998). Whether HPA axis activation negatively affects SERT function to produce increased ECF 5-HT has not been extensively investigated, and the literature that does exist is mixed, with decreases (Maines et al., 1999; McKittrick et al., 2000; Jahng et al., 2007) or no change (Watanabe et al., 1993; Fernandez et al., 2001; Dias Soares et al., 2003; Williams et al., 2005; Chen et al., 2008) in SERT expression in ex vivo rodent forebrain preparations being reported. These discrepancies could be due to differences in the magnitude and/or chronicity of HPA axis activation or the specific brain region examined. Methodological differences and inaccuracy of ex vivo measurements of SERT status could also be contributing factors, given none of the studies have directly examined SERT function in vivo. However, a highly feasible and intriguing possibility is that HPA axis activation does not increase ECF 5-HT by impairing SERT-mediated clearance, but that other 5-HT clearance mechanisms are affected.

Of particular note is the organic cation transporter 3 (OCT3), which acts as a low-affinity, high-capacity transporter of 5-HT (Koepsell et al., 2007). We recently unmasked the contribution of OCT3 to 5-HT clearance in knock-out mice lacking SERT, where 
OCT3 is upregulated (Baganz et al., 2008). Furthermore, and consistent with a contribution to HPA axis-related impairment of 5-HT clearance, OCT3 is widely expressed in forebrain targets of glucocorticoids, including hippocampus (Gasser et al., 2009), and is functionally inhibited by corticosterone (Gründemann et al., 1998; Gasser et al., 2006). Beyond this, however, possible functional interactions between the HPA axis and OCT3 have yet to be determined.

Here, we determine the effects of repeated swim on 5-HT clearance in mouse hippocampus in vivo, using high-speed chronoamperometry. We then used a combination of mutant, pharmacological, and behavioral approaches to elucidate the transporter mechanisms underlying these effects. Our data indicate that repeated HPA axis activation induced by swim compromises 5-HT clearance in vivo. Moreover, we found this effect to be independent of SERT, but dependent upon corticosterone, and associated with loss of OCT3 expression and function.

\section{Materials and Methods}

\section{Animals}

In the majority of experiments, male C57BL/6J mice were used and purchased from Jackson Laboratory. In a subset of experiments, male SERT knock-out (KO) mice (backcrossed to C57BL/6J for $>10$ generations) were used. We maintain a breeding colony of SERT wild-type $(+/+)$, heterozygote $(+/-)$, and homozygote $\mathrm{KO}(-/-)$ mice (originally provided by Dr. Dennis Murphy, National Institute of Mental Health, Bethesda, MD). SERT KO mice were generated and maintained as described previously (Bengel et al., 1998). Male mice weighing 25 to $30 \mathrm{~g}$ were used for all experiments. All animal procedures were in strict accordance with the National Institutes of Health Guide for the Care and Use of Laboratory Animals. All measures were taken to limit the number of animals used and to minimize animal discomfort.

Mice were housed on a standard light cycle with lights on at 7:00 A.M. and off at 7:00 P.M. In mice, circulating corticosterone levels typically peak around the onset of the active period (Moore and Eichler, 1972; Buijs et al., 1993; La Fleur et al., 1999; Li et al., 2006), which would equate to $\sim 6: 00-7: 00$ P.M. in our studies. All experimental manipulations and data acquisition took place before this peak. Mice were swum between 9:00 A.M. and 10:30 A.M. Tail suspension tests (TSTs) were performed between 9:00 A.M. and 12:00 noon, chronoamperometry recordings were made over the period from 10:00 A.M. and 6:00 P.M., and trunk blood was collected at $\sim 6: 00$ P.M.

\section{Repeated swim}

We selected repeated daily exposure to $10 \mathrm{~min}$ of swim as it is a known activator of the HPA axis and produces transient increases in extracellular 5-HT. For example, Boyce-Rustay et al. (2007) showed that plasma corticosterone levels measured $30 \mathrm{~min}$ after either one $10 \mathrm{~min}$ swim or after $14 \mathrm{~d}$ of swimming $10 \mathrm{~min} / \mathrm{d}$ were significantly elevated compared with nonswum control mice. Microdialysis studies revealed that exposure to one or two consecutive swims ( $2 \mathrm{~h}$ apart) causes a rapid increase in ECF 5-HT in mouse hippocampus, peaking within a few minutes following swim and declining to baseline levels $\sim 40$ min later (Yoshitake et al., 2004).

Animals were housed in groups of two or four. Half of the mice in each group received a $10 \mathrm{~min}$ swim for $14 \mathrm{~d}$, while the other half remained in the home cage, as previously described (Boyce-Rustay et al., 2007). The swim tank consisted of a transparent Plexiglas cylinder $(20 \mathrm{~cm}$ diameter $)$ filled half way with water $\left(24 \pm 1^{\circ} \mathrm{C}\right)$. Immediately following the swim, mice were towel dried before being returned to their home cage. In most instances, separate cohorts of mice were used for the in vivo electrochemistry, neurochemistry, and behavioral studies. Quantitative autoradiography was performed using brains from mice that were harvested immediately following chronoamperometric recordings. All experiments commenced $24 \mathrm{~h}$ after the final swim.

\section{In vivo electrochemistry}

In vivo chronoamperometry was performed according to the methods described by Daws and Toney (2007). We constructed our own carbon fiber electrodes, and a detailed description can be found in Williams et al. (2007). Recording electrode/micropipette assemblies were constructed using a single carbon fiber ( $30 \mu \mathrm{m}$ diameter; Specialty Materials), which was sealed inside fused silica tubing (Schott North America). We based our procedure for electrode construction on modifications of published methods (Gerhardt, 1995; Perez et al., 2006). Carbon fiber electrodes (30 $\mu \mathrm{m}$ tip diameter) were coated with Nafion (5\% solution; Aldrich) to prevent interference from anionic substances in extracellular fluid as previously described (Daws and Toney, 2007). Electrodes were tested for sensitivity to the 5-HT metabolite, 5-hydroxyindoleacetic acid (5-HIAA) $(250 \mu \mathrm{M})$ and calibrated with accumulating concentrations of 5-HT $(0-4$ $\mu \mathrm{M})$. Only electrodes displaying a selectivity ratio for 5-HT over 5-HIAA $>500: 1$ and a linear response $\left(r^{2} \leq 0.9\right)$ to 5 -HT were used.

The electrochemical recording assembly consisted of a Nafion-coated, single-carbon fiber electrode attached to a four-barreled micropipette such that their tips were separated by $\sim 200 \mu \mathrm{m}$. Depending on the experimental design (see details below under the subheadings of "Serotonin clearance" through "Histamine clearance"), barrels were filled with combinations of 5-HT $(200 \mu \mathrm{M})$, histamine $(200 \mu \mathrm{M})$, fluvoxamine (FVX) (400 or $800 \mu \mathrm{M})$, corticosterone $(2 \mathrm{~mm})$, or vehicle PBS with or without ethanol (EtOH) (6 mM). Serotonin and histamine were prepared in $0.1 \mathrm{M}$ PBS with $100 \mu \mathrm{M}$ ascorbic acid added as an antioxidant and the $\mathrm{pH}$ adjusted to 7.4. The electrode-micropipette recording assembly was lowered into the CA3 region of the dorsal hippocampus (anteroposterior, -1.94 from bregma; mediolateral, +2.0 from midline; dorsoventral, -2.0 from dura) (Franklin and Paxinos, 1997) of anesthetized mice. We chose to study the CA3 region because this is a neural target for both stress (Watanabe et al., 1992; Holmes and Wellman, 2009) and antidepressant drugs (de Montigny et al., 1990), and because we have previously shown that 5 -HT clearance in this region is mediated primarily by SERT (and not norepinephrine, dopamine, or organic cation transporters) when exogenously applied 5-HT concentrations are $\leq 1 \mu \mathrm{M}$ (Daws et al., 2005; Daws and Toney, 2007; Baganz et al., 2008; Daws, 2009).

For all experiments, mice were anesthetized by intraperitoneal injection ( $2 \mathrm{ml} / \mathrm{kg}$ body weight) of a mixture of chloralose $(35 \mathrm{mg} / \mathrm{kg})$ and urethane $(350 \mathrm{mg} / \mathrm{kg})$. A tube was inserted into the trachea to facilitate breathing, and mice were then placed into a stereotaxic frame. Body temperature was maintained at $36-37^{\circ} \mathrm{C}$ by a watercirculated heating pad.

High-speed chronoamperometric recordings were made using the FAST-12 and FAST-16 systems (Quanteon) (Montañez et al., 2003). Oxidation potentials consisted of $100 \mathrm{~ms}$ pulses of $+0.55 \mathrm{~V}$. Each pulse was separated by a $900 \mathrm{~ms}$ interval during which the resting potential was maintained at $0.0 \mathrm{~V}$. Voltage at the active electrode was applied with respect to an $\mathrm{Ag} / \mathrm{AgCl}$ reference electrode positioned in the extracellular fluid of the ipsilateral superficial cortex. The oxidation and reduction currents were digitally integrated during the last $80 \mathrm{~ms}$ of each $100 \mathrm{~ms}$ voltage pulse.

At the conclusion of the experiment, an electrolytic lesion was made to mark the placement of the electrode tip. The brain was removed, rapidly frozen on dry ice, and stored at $-80^{\circ} \mathrm{C}$ until use. At this time, brains were thawed to $-15^{\circ} \mathrm{C}$ and sliced into $20-\mu \mathrm{m}$-thick sections for histological verification of electrode localization. Only data from mice in which the electrode was confirmed to be in the CA3 region of the hippocampus were included in data analyses. An insufficient number of placements falling outside this region prevented assessment of drug effects on 5-HT clearance in other hippocampal regions.

Electrode reliability. The electrodes were not postcalibrated in these studies. We have performed postcalibrations in the past and found that electrodes decline in sensitivity to 5-HT over time; depending on the duration of the experiment, this decline can range from 5 to $50 \%$. Importantly, however, this decline occurs at a very similar rate; therefore, the interelectrode variability between experiments is very constant. Because of this, we ensure that the timing of protocols and drug challenges is kept as similar as possible between experiments (but ensuring a randomized design to avoid order effects of drug administration). That is, 
when comparing 5-HT clearance rates between control and swum mice, in wild-type or SERT KO mice, this is done in a time-matched manner. In addition, after establishing a stable baseline (i.e., 3 consecutive 5-HT signals of the same amplitude, time course, and clearance rate), we routinely switch out electrodes during the experiment if we find that signal amplitude (the best indicator of lost sensitivity) for a given amount of 5 -HT declines by $>20 \%$. We find this occurs in $<5 \%$ of experiments and with equivalent frequency across treatment groups. Combined, these strategies minimize potential confounds that may be introduced by loss of electrode sensitivity.

Drug effects on electrode sensitivity for serotonin. It is known that some compounds can interfere with the sensitivity of carbon fiber electrodes to detect neurotransmitter (Davidson et al., 2000). Because of this, we tested the effect of fluvoxamine, corticosterone, and $\mathrm{EtOH}$ (vehicle for corticosterone) on electrode sensitivity for 5-HT. To do this, Nafion-coated carbon fiber electrodes were calibrated to 5-HT $(0.2-1.0 \mu \mathrm{M}$ in $0.2 \mu \mathrm{M}$ increments) in a beaker containing PBS according to standard protocol (Daws and Toney, 2007). Each electrode was calibrated twice, the first time in the absence of drug or vehicle and the second time after the addition of drug or vehicle. Drug concentrations were based on those estimated to reach the recording electrode following pressure ejection into brain. Based on our own estimates and that of others (Gerhardt and Palmer, 1987; Daws et al., 2006), the concentration of drug pressure ejected a distance of $\sim 200 \mu \mathrm{m}$ from the recording electrode is diluted on the order of 10- to 200-fold by the time it reaches the recording site. Thus, in these experiments we tested drugs at both the low and high end of this range. The concentrations tested were, respectively, 2 and $80 \mu \mathrm{M}$ for fluvoxamine, 10 and $200 \mu \mathrm{M}$ for corticosterone, and 30 and $600 \mu \mathrm{M}$ for EtOH. An equivalent volume of PBS was added as the control.

Sensitivity was determined as the slope of the calibration curve. As expected under control conditions, the sensitivity of the electrode for 5 -HT declined after the first calibration by $\sim 30 \%(69 \pm 15 \%$; $n=3$; slope of second calibration as a percentage of first calibration). Neither corticosterone nor $\mathrm{EtOH}$, at either concentration, changed the sensitivity of the Nafion-coated carbon fiber electrode for 5-HT compared with the PBS control. Expressed as a percentage of the control condition, the sensitivity of the electrode following corticosterone was $100 \pm 26 \%(n=$ 5, 10 and $200 \mu \mathrm{M}$ pooled), and following EtOH, $115 \pm 14 \%(n=6,30$ and $600 \mu \mathrm{m}$ pooled). There was a nonsignificant trend for fluvoxamine $(2.0 \mu \mathrm{M})$ to reduce the sensitivity of the electrode for 5-HT [PBS, $100 \pm$ $23 \%(n=3)$ vs fluvoxamine, $68 \pm 15 \%(n=6)]$. The higher fluvoxamine concentration $(80 \mu \mathrm{M})$ reduced the sensitivity of the electrode for 5-HT $(15 \pm 3 \%, n=3)$. It is important to note however, that we do not find any evidence for fluvoxamine interfering with electrode sensitivity for 5-HT under our in vivo recording scenario. For example, 5-HT signals remain reproducible following intrahippocampal application of fluvoxamine (200 $\mu \mathrm{M}$ barrel concentration) to SERT KO mice (Montañez et al., 2003). Together, these results support the view that drugs are diluted much in excess of 10 -fold, and perhaps even $>200$-fold, by the time they diffuse the $200 \mu \mathrm{m}$ from the micropipette to the recording electrode. None of the conditions significantly changed the selectivity of the electrodes for 5-HT over 5-HIAA. The implication is that the data presented in the current study are not confounded by drugs interfering with the sensitivity or selectivity of the carbon fiber electrode for 5-HT.

\section{Serotonin clearance}

We first assessed basal 5-HT clearance in the CA3 region of the hippocampus of mice exposed to repeated swim $(10 \mathrm{~min} / \mathrm{d}$ for $14 \mathrm{~d})$ or not exposed to swim. Serotonin $(2.5,5.0,10.0$, or $20.0 \mathrm{pmol})$ was locally pressure ejected into the hippocampus to obtain 5-HT signals with increasing amplitude (micromolar units). Current induced by oxidation of 5-HT at the carbon fiber recording electrode was measured as a function of time and converted to micromolar units based on a calibration factor determined before the experiment in vivo (for details, see Daws and Toney, 2007).

\section{Effect of local fluvoxamine on 5-HT clearance in hippocampus}

Exogenous 5-HT was applied in the CA3 region of the hippocampus by pressure ejection (5-25 psi for 0.25-3.0 s). Advantages of this approach are that clearance can be measured without an associated "release" component and that measurements can be made in vivo with excellent temporal (milliseconds) resolution. The amount of 5-HT pressure ejected was adjusted so that baseline peak signal amplitudes did not exceed 1.0 $\mu \mathrm{M}$. By keeping signal amplitudes in this range, we can maintain the sensitivity of the electrode for 5-HT for several hours and, importantly, provide conditions that favor SERT-mediated 5-HT uptake.

Once reproducible 5-HT electrochemical signals were obtained, fluvoxamine or PBS vehicle was applied locally into the CA3 region of hippocampus 2 min before the next application of 5-HT. Different amounts of fluvoxamine (in picomoles) were delivered by varying the barrel concentration of drug $(400$ or $800 \mu \mathrm{M})$ as well as the volume ejected. This drug application protocol was chosen to cause minimal disturbance to the baseline electrochemical signal and to allow sufficient time for drugs to diffuse to the recording site. Three signal parameters were analyzed: the peak signal amplitude; the $\mathrm{T}_{80}$ time course parameter, defined as the time for the signal to decline by $80 \%$ of the peak signal amplitude; and the clearance rate (Tc), defined as the slope of the most linear portion of the descending limb of the signal, between $\mathrm{T}_{20}$ and $\mathrm{T}_{60}$ (the time for the signal to decline by 20 to $60 \%$ of the peak signal amplitude).

As noted earlier, the concentration of drug reaching the recording electrode is likely greater than 200 -fold less than the concentration of drug within the barrel (Daws et al., 2006). Thus, barrel concentrations were determined to achieve concentrations of drug reaching the recording site in a range that would yield pharmacologically and physiologically relevant concentrations.

\section{Effect of local corticosterone on 5-HT clearance in hippocampus}

These experiments were performed as described for fluvoxamine, with two notable exceptions. To favor detection of OCT3-mediated 5-HT clearance, $5-\mathrm{HT}$ signals in a range of $2-4 \mu \mathrm{M}$ were obtained. Second, the barrel concentration of corticosterone was $2 \mathrm{~mm}$. We have previously shown that a corticosterone barrel concentration of $100 \mu \mathrm{M}$ does not affect 5-HT clearance in C57BL/6 $\mathrm{J}$ mice, but does impede 5-HT clearance in SERT-deficient mice where OCT3 expression is elevated (Baganz et al., 2008). Therefore, we used this relatively high concentration of corticosterone to increase the likelihood of detecting an ability of corticosterone (an OCT3 blocker) to inhibit 5-HT clearance in C57BL/6J mice exposed to repeated swim, compared with control mice. The vehicle for corticosterone was PBS containing $6 \mathrm{~mm}$ EtOH. This would yield a concentration of $\sim 0.03 \mathrm{~mm}$ EtOH at the recording site, a concentration that does not influence 5-HT clearance when signal amplitudes are kept at $<1 \mu \mathrm{M}$ (Daws et al., 2006).

\section{Histamine clearance}

To directly assess the function of OCT3, we measured clearance of the high-affinity substrate histamine $(200 \mu \mathrm{M}$ barrel concentration and delivering $140 \mathrm{pmol}$ ) in the CA3 region of the hippocampus of mice exposed to 0 or $14 \mathrm{~d}$ of swim using chronoamperometry. These experiments were performed in the same way as described above for 5-HT clearance with the following exceptions. The sensitivity for carbon fiber electrodes is much lower for histamine than 5-HT. Therefore, to increase the surface area of the electrode we created microfractures in the carbon fiber by applying a potential of $+1.50 \mathrm{~V}$ for $100 \mathrm{~ms}$ and stepping back to a resting potential of $-1.50 \mathrm{~V}$ for $100 \mathrm{~ms}$ for a period of $10 \mathrm{~min}$ before coating the electrode with Nafion, calibrating in vitro, and recording in vivo. Histamine is oxidized at a higher potential than 5-HT, and so for in vivo recordings $100 \mathrm{~ms}$ pulses of $+1.0 \mathrm{~V}$ were applied (compared with $0.55 \mathrm{~V}$ for 5 -HT recordings). Each pulse was separated by a $900 \mathrm{~ms}$ interval, during which the resting potential was maintained at $0.0 \mathrm{~V}$.

\section{Quantitative autoradiography}

A separate cohort of animals was exposed to repeated swim, or not, as described above, and $24 \mathrm{~h}$ following the final swim mice were killed by rapid decapitation; brains were rapidly removed, frozen on dry ice, and stored at $-80^{\circ} \mathrm{C}$ until use. Coronal, $20 \mu \mathrm{m}$ brain sections were cut in a cryostat and mounted onto gelatin-coated slides.

To determine SERT expression level, we used quantitative autoradiography to measure binding of the SERT-specific radioligand $\left[{ }^{3} \mathrm{H}\right]$ - 
cyanoimipramine (CN-IMI) (80-85 Ci/mmol; American Radiolabeled Chemicals) in hippocampus of whole brain sections, as described by Hensler et al. (1994). Slide-mounted sections were incubated with $\left[{ }^{3} \mathrm{H}\right] \mathrm{CN}-\mathrm{IMI}(1 \mathrm{~nm})$ in a buffer of $50 \mathrm{~mm}$ Tris, $\mathrm{pH} 7.4$, and $120 \mathrm{~nm} \mathrm{NaCl}$ at $4^{\circ} \mathrm{C}$ for $24 \mathrm{~h}$. Nonspecific binding was defined in the presence of $1 \mu \mathrm{M}$ fluvoxamine. Sections were then washed in cold buffer $\left(4^{\circ} \mathrm{C}\right)$ and dipped in cold distilled water. At the end of the autoradiographic assay, sections were dried on a slide warmer at $60^{\circ} \mathrm{C}$ and apposed to Kodak Biomax MR film (GE Healthcare) for 4 weeks to generate autoradiograms. Analysis of the digitized autoradiograms was performed using the image analysis program NIH Image, version 1.47 (National Institutes of Health), and optical densities of brain images were converted to femtomoles/milligram protein. The concentration of $\left[{ }^{3} \mathrm{H}\right] \mathrm{CN}$-IMI used is approximately eight times its $K_{D}$ value (Kovachich et al., 1988), so the values obtained approximate $B_{\max }$ values.

\section{Western blot analysis}

Brains were removed from mice killed by rapid decapitation, and hippocampi were dissected out on ice and stored at $-80^{\circ} \mathrm{C}$ until use. Samples were suspended in $500 \mu \mathrm{l}$ of ice-cold PBS $(0.1 \mathrm{M}, \mathrm{pH} 7.4)$ and pulsed in a centrifuge. The supernatant was removed, and the pellets were then homogenized in $500 \mu$ l of homogenizing buffer (25 mM HEPES, $25 \mathrm{~mm}$ sucrose, $1.5 \mathrm{~mm} \mathrm{MgCl}_{2}, 50 \mathrm{~mm} \mathrm{NaCl}$, pH 7.2, aprotinin, leupeptin, pepstatin, and PMSF) using glass Potter-Elvehjem tissue grinders. Total protein concentrations of each sample were measured by Bradford protein assay (Bradford, 1976). Samples were solubilized in a buffer containing bromophenol blue, heated for $5 \mathrm{~min}$ at $95^{\circ} \mathrm{C}$, and separated by electrophoresis using SDS-PAGE. Protein was then transferred to a polyvinylidene difluoride membrane (Immobilon-P, Millipore). The membrane was blocked in 5\% nonfat dry milk in $1 \times$ TBS-Tween at room temperature for $1 \mathrm{~h}$, washed twice with $1 \times$ TBS-Tween, and incubated overnight at $4^{\circ} \mathrm{C}$ with polyclonal OCT3 antibody (catalog \#OCT31-A; Alpha Diagnostics International). The primary antibody was then removed, and the membrane was washed three times and incubated for $1 \mathrm{~h}$ at $4^{\circ} \mathrm{C}$ with the secondary enhanced chemiluminescence donkey antirabbit IgG horseradish peroxidase-linked antibody (1:2500) (GE Healthcare). Bound antibody was detected on x-ray film using enhanced chemiluminescence reagents (GE Healthcare). Note that affinitypurified rabbit polyclonal OCT3 primary antibodies used here were generated against a 19 aa C-terminal cytoplasmic domain of mouse OCT3. This peptide has no significant sequence homology with other mouse OCTs. Together with our previously published immunohistochemical data using the same antibody and controlling for nonspecific staining (Baganz et al., 2008), the antibody used in these studies appears to be highly specific for OCT3.

\section{Adrenalectomy}

Mice were anesthetized with isoflurane (3\%), and bilateral adrenalectomy (ADX) was performed according to Castro (1974). Sham-operated animals were surgically incised to visually identify intact adrenal glands. Incisions were sutured, and animals were allowed to recover from surgery for 1 week before exposure to repeated forced swim. Drinking water was replaced with $0.45 \%$ saline for ADX mice.

\section{Corticosterone radioimmunoassay}

Immediately following chronoamperometry recordings in ADX or sham-operated mice (i.e., $\sim 30 \mathrm{~h}$ after the last swim), the animals were killed, and trunk blood was collected for analysis of corticosterone content. Blood was centrifuged ( $6000 \mathrm{rpm}$ for $15 \mathrm{~min}$ ) with $300 \mu \mathrm{l}$ of EDTA (anticoagulant), and plasma was separated according to methods described by Li et al. (1999) (also, Q. Li, personal communication). Plasma corticosterone concentration was measured using a radioimmunoassay (RIA) kit purchased from MP Biomedicals (catalog \#07120102), as described by the manufacturer.

\section{Tail suspension test}

A separate cohort of mice was used to assess the effect of the selective serotonin reuptake inhibitors (SSRIs) fluvoxamine and fluoxetine (FLX), as well as the selective norepinephrine uptake inhibitor desipramine (DMI) on behavior. Mice were exposed to 0 or $14 \mathrm{~d}$ of swim, as described. Twenty-four hours after the final swim, mice were administered fluvoxamine $(30 \mathrm{mg} / \mathrm{kg})$, fluoxetine $(15 \mathrm{mg} / \mathrm{kg})$, DMI $(15 \mathrm{mg} / \mathrm{kg})$ (dissolved in $0.9 \% \mathrm{v} / \mathrm{v}$ saline, injected intraperitoneally at $10 \mathrm{ml} / \mathrm{kg}$ body weight), or saline control. Thirty minutes following injection, the TST was performed as previously described (Steru et al., 1985). Mice were secured and suspended by the distal end of the tail to a flat metallic surface for $6 \mathrm{~min}$. The presence or absence of immobility, defined as the absence of movement other than passive swaying, was sampled every $5 \mathrm{~s}$ over 6 min by a trained observer who remained blind to treatment (Boyce-Rustay et al., 2006).

\section{Data analyses}

Data are presented as the mean and SEM and analyzed with ANOVA followed by Bonferroni or Newman-Keuls post hoc comparisons or $t$ tests for independent samples. The threshold for statistical significance was set at $p<0.05$.

\section{Drugs}

Serotonin, 5-HIAA, histamine, corticosterone, desipramine, fluvoxamine, urethane, and chloralose were purchased from Sigma. Fluoxetine was purchased from LKT Laboratories.

\section{Results}

\section{Repeated swim impairs hippocampal 5-HT clearance}

To determine whether impaired SERT activity could account for increased ECF 5-HT in hippocampus following repeated swim (Yoshitake et al., 2004), we first measured clearance of exogenously applied 5-HT from ECF in the CA3 region of the hippocampus in vivo, using high-speed chronoamperometry. Male C57BL/6J mice were subjected to 14 consecutive days of $10 \mathrm{~min} / \mathrm{d}$ swim and, $1 \mathrm{~d}$ later, 5-HT clearance was measured, under anesthesia, and compared with age-/weight-matched mice not exposed to swim. We found that 5-HT clearance kinetics in controls were similar to those previously reported for mice on this genetic background (Montañez et al., 2003). However, clearance rate was markedly reduced in mice with a history of repeated swim, compared with controls (Fig. $1 A, B$ ). Specifically, while the clearance rate increased with increasing concentrations of 5-HT (ANOVA: $\left.F_{(3,54)}=10.98 ; p<0.01\right)$, clearance rate was significantly slower in mice with a history of repeated swim than in controls $\left(F_{(1,54)}=\right.$ 23.96; $p<0.01$ ) (Fig. 1 $A, B$ ). There was also a significant interaction between repeated swim and 5-HT concentration $\left(F_{(3,54)}=4.31, p<\right.$ 0.01 ) because of the slower 5-HT clearance rate in mice exposed to repeated swim compared with controls at the highest (10 and 20 pmol) 5-HT concentrations (Bonferroni post hoc test, $p<0.05$ ).

We found that reduced 5 -HT clearance rate was associated with a decreased time course for clearance, quantified as $T_{80} \cdot T_{80}$ values in mice exposed to repeated swim were significantly longer than in controls at the highest $(20 \mathrm{pmol}) 5$-HT concentration (effect of swim: $F_{(1,54)}=9.42 ; p<0.01$; Bonferroni post hoc test, $p<0.05$ ) (Fig. 1C). Importantly, while 5-HT signal amplitude showed an expected increase with increasing 5-HT concentration (effect of concentration $F_{(3,54)}=14.92, p<0.01$ ), this measure did not differ between swum and control groups (Fig. $1 D$ ). This indicates that slower 5-HT clearance in mice exposed to repeated swim was not an artifact of factors that can affect 5-HT diffusion from the micropipette through the extracellular milieu to the recording electrode, such as changes in volume fraction or tortuosity. Thus, the major novel result of this experiment is that repeated swim produced a profound impairment in hippocampal 5-HT clearance in vivo. The finding that this deficit was selectively manifested at high 5-HT concentrations ( $>5$ micromolar) was notable, because this is a concentration range where non-SERT clearance mechanisms are known to begin to exert an influence over clearance (Daws et al., 2005; Baganz et al., 2008; for review, 

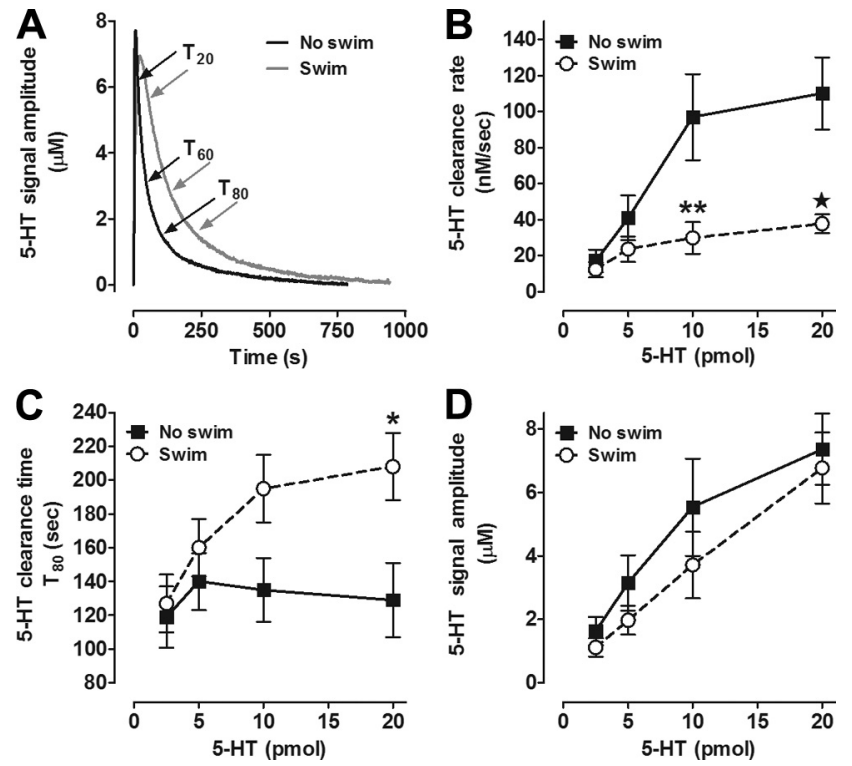

Figure 1. Serotonin clearance is impaired in the CA3 region of the hippocampus of mice subjected to repeated swim. $A$, Representative oxidation currents (converted to 5 -HT concentration, $\mu \mathrm{M}$ ) produced by locally applied 5 -HT (barrel concentration $200 \mu \mathrm{M}$ ) in the CA3 region of the hippocampus of mice exposed to $0 \mathrm{~d}$ (black line) or $14 \mathrm{~d}$ (gray line) of swim. Raw traces are superimposed for ease of comparison. Time of clearance is $\mathrm{T}_{80}(\mathrm{~s})$, defined as the amount of time it takes for the signal to decline by $80 \%$ of its peak amplitude. The Tc is defined here as the slope of the most linear portion of the descending signal ranging from $\mathrm{T}_{20}$ to $\mathrm{T}_{60} . B, C$, Compared with controls, 5 -HT clearance rate $(\mathrm{nm} / \mathrm{s})$ is slower $(\boldsymbol{B})$ and time $(\mathrm{s})$ is longer $(\boldsymbol{C})$ in hippocampus of mice swum for $14 \mathrm{~d}$ (2-way ANOVA with Bonferroni post hoc comparison, ${ }^{*} p<0.05$; ${ }^{* *} p<$ $0.01 ; \star p<0.01 ; n=5-9 /$ group/pmol amount). $\boldsymbol{D}$, For a given amount of 5-HT (pmol) administered, $5-\mathrm{HT}$ signal amplitudes $(\mu \mathrm{m})$ were equivalent in both groups of mice.
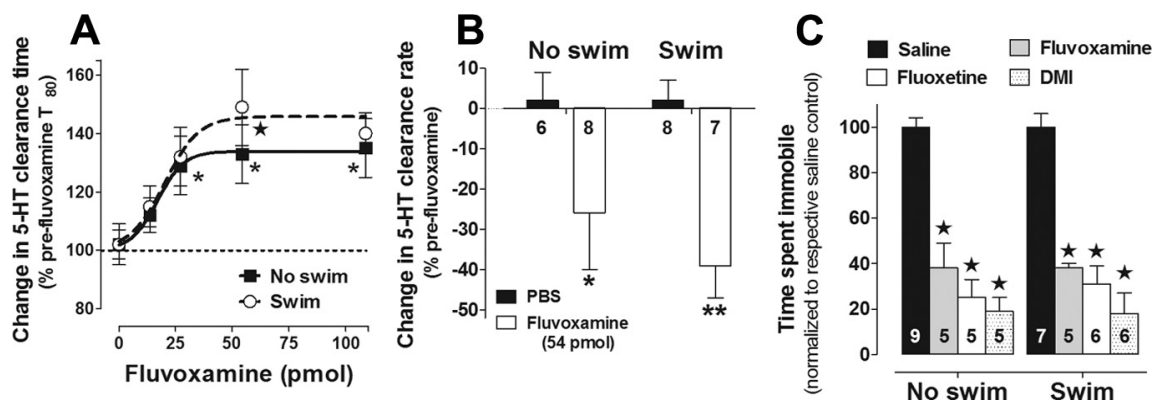

Figure 2. SERT function and expression is the same in mice subjected to 0 or $14 \mathrm{~d}$ of repeated swim. $\boldsymbol{A}, \boldsymbol{B}$, As expected fluvoxamine inhibited 5-HT clearance time $(\boldsymbol{A})$ and rate $(\boldsymbol{B})$ in hippocampus of control mice (no swim); however, these effects of fluvoxamine were equivalent in mice exposed to repeated swim. Compared with PBS vehicle, fluvoxamine significantly slowed 5 -HT clearance time and rate in both groups of mice (2-way ANOVA with Bonferroni post hoc test, ${ }^{*} p<0.05$; ${ }^{* *} p<0.01, \star p<$ $0.01, n=5-9 /$ group/dose). , In a behavioral readout of SERT and NET function, repeated swim did not affect the response to SERT and NET blockers in the tail suspension test. Immobility was sampled every 5 s over a 6 min test. Compared with saline, fluvoxamine (30 $\mathrm{mg} / \mathrm{kg}$ ), fluoxetine $(15 \mathrm{mg} / \mathrm{kg})$, and DMI (15 mg/kg) reduced immobility time in the TST in both groups of mice equally, regardless of swim. Data are expressed as a percentage of respective saline control (2-way ANOVA with Bonferroni post hoc test, $\star p<0.01$ ).

see Daws, 2009). Thus, although SERT would be the most likely a priori mechanism explaining the 5-HT clearance-impairing effects of repeated swim, other transporter mechanisms could also be involved. To address this issue, we first conducted a set of experiments to establish whether SERT function was altered by repeated swim.

Repeated swim does not decrease SERT expression or function in wild-type mice, and decreases 5-HT clearance in SERT KO mice

To determine the consequences of repeated swim for SERT function, we began by testing whether the SERT-inhibiting effects of the SSRI FVX were intact after repeated swim. Assessing the capacity of FVX to inhibit 5-HT clearance provides a sensitive measure of changes in SERT function (Montañez et al., 2003). One day after the repeated swim regime, we locally applied increasing concentrations of FVX in the CA3 hippocampus and then examined the clearance of exogenously applied 5-HT using chronoamperometry, as above. Here, we limited the concentration of 5-HT reaching the recording electrode to $<1 \mu \mathrm{M}$ to optimize conditions for detecting SERT, as opposed to non-SERT, mediated 5-HT uptake (Daws and Toney, 2007; Baganz et al., 2008).

Consistent with our results above (Fig. $1 B, C$ ), baseline, preFVX, clearance of this low 5-HT concentration was not different between repeated swim and control groups (Tc: $6.41 \pm 0.30 \mathrm{~nm} / \mathrm{s}$ and $6.98 \pm 0.47 \mathrm{~nm} / \mathrm{s} ; \mathrm{T}_{80}: 81 \pm 5 \mathrm{~s}$ and $84 \pm 5 \mathrm{~s}$; for the same signal amplitude: $0.53 \pm 0.01 \mu \mathrm{M}$ and $0.56 \pm 0.02 \mu \mathrm{M} ; n=21$ and $n=14$, respectively), providing further evidence that repeated swim does not affect clearance when SERT is the dominant transport mechanism. In line with our previous findings (Montañez et al., 2003), FVX dose-dependently inhibited 5-HT clearance $\left(F_{(4,63)}=5.79 ; p<0.01\right)$. However, 5-HT clearance after FVX did not differ between mice subjected to repeated swim and control mice, as measured by $\mathrm{T}_{80}$ time course (Fig. $2 \mathrm{~A}$ ) as well as clearance rate (Fig. $2 B$ ). Furthermore, in CA3 hippocampal tissue taken at the completion of the chronoamperometry analysis and processed for quantitative autoradiography with the SERTselective radioligand $\left[{ }^{3} \mathrm{H}\right] \mathrm{CN}$-IMI, we found no difference in maximal SERT binding between groups ( $1192 \pm 83$ vs $1261 \pm 69$ $\mathrm{fmol} / \mathrm{mg}$ protein, respectively, for control and mice exposed to repeated swim). Thus, the retention of the ability of FVX to inhibit 5-HT clearance, together with the lack of changes in SERT expression, demonstrates there was no clear loss of SERT function following repeated swim. One caveat here is that FVX and 5-HT might target different binding pockets within SERT (Andersen et al., 2009); therefore, our FVX data cannot rule out the possibility that repeated swim impaired SERT function by interfering with the translocation of 5-HT via SERT.

As another means to assay SERT function, we turned to a behavioral paradigm. Wild-type C57BL/6J mice were subjected to repeated swim for $14 \mathrm{~d}$ and tested on the TST $1 \mathrm{~d}$ later. The TST is a simple measure of "behavioral despair" that is reliably sensitive to acute treatment with antidepressant drugs, which reduce the time mice spend immobile (e.g., Cryan and Holmes, 2005). We tested groups of swum and nonswum mice $30 \mathrm{~min}$ after intraperitoneal injection of saline, the SERTtargeting antidepressants FVX and FLX, or the norepinephrine transporter (NET)-targeting antidepressant DMI. This provided another means to evaluate possible changes in SERT (and NET) function after repeated swim, this time at the behavioral level.

We found that FVX, FLX, and DMI treatments all significantly and equivalently reduced immobility time, regardless of swim history (effect of drug: $F_{(3,40)}=59.98 ; p<0.01$ ) (Fig. $2 C$ ). Time spent immobile (scored every $5 \mathrm{~s}$ over a 6 min test as the absence of movement other than passive swaying) was $38 \pm 2$ and $29 \pm 2$ counts, respectively, for nonswum mice and mice exposed to repeated $\operatorname{swim}\left(t_{(14)}=3.54 ; p<0.01\right)$ (i.e., $53 \pm 2 \%$ and $41 \pm 3 \%$ 
of a total of 72 possible counts, respectively, were spent immobile in nonswum and swum mice). These data provide further evidence that SERT (and NET) function is unaltered by repeated swim, and that functional alteration in other transporter mechanisms likely drive the reduced rate of 5-HT clearance observed in our in vivo electrochemistry studies.

To definitively rule out a role for SERT, we turned to a gene mutant approach. Mutant mice with constitutive gene KO of SERT (Murphy et al., 2008) and maintained on a congenic C57BL/6J background were exposed to repeated swim, and then, $1 \mathrm{~d}$ later, clearance of 5-HT from ECF of hippocampus measured using the same procedures as described above. As expected (Montañez et al., 2003), clearance was significantly slower in control SERT KO mice, relative to the values reported above in control C57BL/6J mice tested under the same experimental conditions. This was apparent for clearance rate at the 10 and 20 pmol of 5-HT concentrations (effect of genotype: $F_{(3,89)}=22.06$; Bonferroni post hoc test, $p<0.01$ ) (Fig. 3A). Strikingly, however, not only did SERT KO fail to abolish the effects of repeated swim on 5-HT clearance, but these effects were actually augmented in the $\mathrm{KO}$ mice. That is, repeated swim significantly reduced 5 -HT clearance at 10 and 20 pmol, below the already compromised basal 5-HT clearance rate in SERT KO (i.e., no swim control) (Bonferroni post hoc test, $p<0.01$ ) (Fig. 3A). The effects of repeated swim and SERT genotype are summarized for the 20 pmol concentration in Figure $3 B$. Importantly, as we showed in Figure 1D, while 5-HT signal amplitude showed an expected increase with increasing 5-HT concentration (effect of concentration: $\left.F_{(3,89)}=17.13, p<0.01\right)$, this measure did not differ between swum and control groups (Fig. $3 C$ ).

Together, this series of experiments makes two important points. First, while repeated swim clearly impairs 5-HT clearance, these effects are not associated with any observable changes in SERT function or expression. The second major conclusion is that the 5-HT clearance-impairing effect of repeated swim is retained in the absence of SERT. Therefore, loss of SERT function is unlikely to account for the impairment in 5-HT clearance, and other transporter mechanisms appear to be involved. We next explored one such possible mechanism.

\section{Repeated swim decreases OCT3 expression and impairs OCT3-mediated histamine clearance}

OCT3 is a low-affinity, high-capacity 5-HT transporter (Koepsell et al., 2007) that we and others have shown to regulate 5-HT clearance predominantly under conditions of high 5-HT, and to be upregulated in SERT KO mice (Chen et al., 2001; Feng et al., 2005; Baganz et al., 2008). To test whether OCT3 downregulation might underlie the sluggish rate of 5-HT clearance after repeated swim, we first performed Western blot analysis of OCT3 protein levels in whole hippocampus of C57BL/6J mice with a history of repeated swim. OCT3 density values (normalized to $\beta$-actin) were significantly lower $\left(t_{(18)}=2.40 ; p<0.05\right)$ after repeated swim, relative to non-repeated swim counterparts (Fig. $4 A$ ). To determine OCT3 function in vivo, we turned to measurement of histamine clearance. Histamine is a substrate for OCT3 but not other biogenic amine transporters (Schneider et al., 2005; Gasser et al., 2006). Supporting the utility of histamine clearance as a probe for OCT3 function, we previously found that histamine clearance is faster, and inhibited more robustly by the OCT3 antagonist D-22, in SERT KO mice, where OCT3 is upregulated (Baganz et al., 2008). Therefore, we would predict an impairment in histamine clearance if repeated swim impairs OCT3 function. Consistent with this prediction, when examined $1 \mathrm{~d}$ after the last swim, the $\mathrm{T}_{80}$ time course of locally applied histamine clearance in CA3 hippocampus was significantly longer in C57BL/6J mice exposed to repeated swim than in controls $\left(t_{(6)}=2.99 ; p<0.05\right)$ (Fig. $4 B$ ). The clearance rate of histamine was also significantly slower in the swum mice than in controls $\left(t_{(6)}=9.31, p<0.01\right)$ (Fig. 4C). Thus, both hippocampal OCT3 expression and an OCT3-mediated clearance function are reduced by repeated swim.

The OCT3 antagonist corticosterone inhibits 5-HT clearance at OCT3-recruiting 5-HT concentrations

We recently demonstrated that when the concentration of applied 5-HT was low (signal amplitude, $<1.0 \mu \mathrm{M}$ ), FVX efficiently inhibited hippocampal 5-HT clearance, while the OCT3 antagonist D-22 was ineffective (Baganz et al., 2008). Conversely, at higher 5-HT concentrations $(>2.0 \mu \mathrm{M})$, the pattern of drug effects was reversed-with D-22, but not FVX, inhibiting 5-HT clearance (Baganz et al., 2008). This pattern of drug effect is con- 


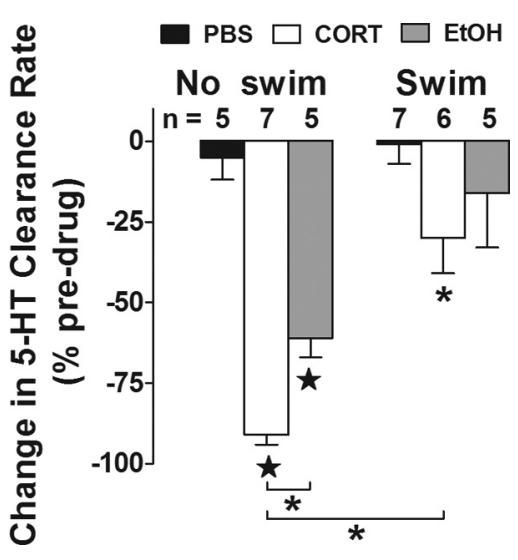

Figure 5. The ability of corticosterone to inhibit 5-HT clearance in hippocampus is dependent on exposure to repeated swim. Change in $5-\mathrm{HT}$ clearance rate (expressed as percentage of baseline) 2 min after hippocampal application of PBS control, EtOH vehicle $(0.8 \mathrm{nmol})$, or corticosterone ( $272 \mathrm{pmol})$ in mice exposed to 0 or $14 \mathrm{~d}$ of swim. In both groups of mice, corticosterone inhibited 5-HT clearance rate, compared with PBS vehicle, but this effect of corticosterone was blunted in mice exposed to repeated swim (2-way ANOVA with Bonferroni post hoc test, $\left.{ }^{*} p<0.05 ; \star p<0.01\right)$. EtOH significantly reduced $5-\mathrm{HT}$ clearance rate only in mice that were not exposed to swim. Predrug/vehicle signal amplitudes did not vary among groups. Pooled values were $3.59 \pm 0.35 \mu \mathrm{M}(n=17)$ and $3.20 \pm 0.18 \mu \mathrm{M}(n=18)$ for 0 and $14 \mathrm{~d}$ swim, respectively. Predrug/vehicle clearance rate was slower in mice exposed to $14 \mathrm{~d}$ swim (31.82 \pm $5.56 \mathrm{~nm} / \mathrm{s})$ compared with control mice $(56.58 \pm 8.4 \mathrm{~nm} / \mathrm{s})\left(t_{(33)}=2.595, p=0.015\right)$.

sistent with OCT3 operating as a low-affinity, high-capacity transporter for 5-HT. It also predicts that antagonists of OCT3, such as corticosterone, should exert demonstrable effects on 5-HT clearance only when 5-HT concentrations are high, as measured by chronoamperometry. Indeed, we previously found that hippocampally applied corticosterone (55 pmol) did not affect clearance of exogenously applied 5-HT when the concentration of 5-HT was low and OCT3 is putatively quiescent (Baganz et al., 2008).

Here, we tested whether corticosterone would reduce 5-HT clearance at a high, OCT3-recruiting, 5-HT concentration $(>2.5$ $\mu \mathrm{M})$, and also whether this effect would be blunted by repeated swim due to OCT3 downregulation. One day after subjecting C57BL/6J mice to $14 \mathrm{~d}$ of $10 \mathrm{~min} / \mathrm{d}$ repeated swim, we locally applied corticosterone (PBS or EtOH vehicle) and measured 5 -HT clearance in CA3 hippocampus. We used a corticosterone concentration of $2 \mathrm{mM}$ in the micropipette to achieve corticosterone concentrations at the recording electrode in the range of 10 $\mu \mathrm{M}$ after accounting for dilution through the extracellular matrix (Daws et al., 2006).

The first notable finding was that corticosterone significantly reduced 5-HT clearance rate compared with PBS (effect of drug: $F_{(2,29)}=21.41 ; p<0.01$ ) (Fig. 5). This demonstrates that exogenous corticosterone is sufficient to mimic the 5-HT clearancedisrupting effects of repeated swim under conditions where OCT3 is a dominant transport mechanism. One potential caveat to note here is that corticosterone was diluted with a small amount of $\mathrm{EtOH}(<0.8 \mathrm{nmol})$, and it is possible that this contributed to the clearance-inhibiting effect of 5-HT, given evidence that, at albeit much higher concentrations $(10 \mathrm{nmol})$, EtOH inhibits 5-HT clearance under high endogenous 5-HT concentrations (Daws et al., 2006). Notwithstanding, the major finding was that while corticosterone reduced 5-HT clearance rate both in mice subjected to repeated swim and control mice, the magnitude of the effect was significantly less in repeated swim mice (effect of swim: $F_{(1,29)}=25.65 ; p<0.01$ ) (Fig. 5). This finding is consistent with a model in which repeated swim causes
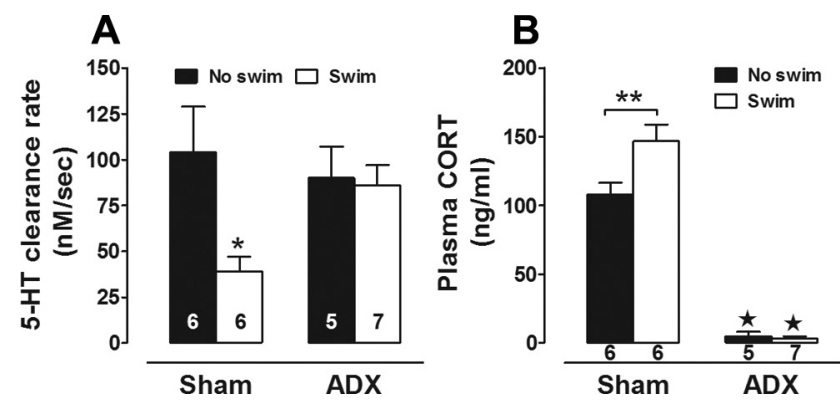

Figure 6. Adrenalectomy abolishes the swim-induced decrease in 5-HT clearance. $A$, Maximal velocity for 5-HT clearance was slower in hippocampus of sham-operated mice exposed to $14 \mathrm{~d}$ of swim (2-way ANOVA with Bonferroni post hoc test, $\star p<0.001$ ), compared with sham-operated mice that were not exposed to swim and ADX mice swum for 0 or $14 \mathrm{~d}$. B, Plasma corticosterone concentration $(\mathrm{ng} / \mathrm{ml})$ was essentially undetectable in ADX mice, regardless of swim, compared with sham-operated mice $(\star p<0.01)$. Corticosterone levels were elevated in sham-operated mice exposed to $14 \mathrm{~d}$ of swim, compared with $0 \mathrm{~d}$ counterparts $\left({ }^{* *} p<0.01\right)$.

functional downregulation of OCT3 to produce loss of hippocampal 5-HT clearance. In our next set of experiments, we interrogated this model further by asking whether disrupting a step upstream of OCT3 downregulation would block the effects of repeated swim.

\section{Repeated swim impairment of 5-HT clearance is prevented by removing corticosterone}

The glucocorticoid corticosterone is released following HPA axis activation by a wide range of environmental factors, including stressors and exercise, and targets various brain regions especially the CA3 subregion of the hippocampus (McEwen, 1999). As noted, we have previously shown that repeated swim causes significant corticosterone release in C57BL/6J mice even after $14 \mathrm{~d}$ (Boyce-Rustay et al., 2007). In much the same way that biogenic amine transporters, including SERT (Hirano et al., 2005) and NET (Weinshenker et al., 2002), are downregulated by repeated administration of transporter-blocking drugs, repeated swim induction of corticosterone release could cause OCT3 downregulation, in turn producing the accompanying deficit in 5-HT clearance we observe.

To test this hypothesis, we eliminated corticosterone by performing ADX on C57BL/6J mice before repeated swim. We examined 5-HT clearance $1 \mathrm{~d}$ after the final swim, limiting our analysis to one high concentration of 5-HT (20 pmol), at which repeated swim effects were most clearly manifest in our earlier experiments. Replicating our earlier experiment, 5-HT clearance rate was significantly slower in sham mice subjected to repeated swim than in sham non-swum controls (effect of swim: $F_{(1,20)}=$ 4.47, $p<0.05$ ) (Fig. 6A). By contrast, while ADX had no effect on clearance rate in non-swum control mice, the reduction in clearance rate produced by repeated swim was completely prevented by ADX (Fig. 6A). RIA analysis of plasma samples taken immediately after the chronoamperometry recordings (i.e., $\sim 30 \mathrm{~h}$ after the last swim) confirmed that corticosterone was elevated in nonADX swum mice relative to non-ADX, non-swum controls (effect of swim: $\left.F_{(1,20)}=5.89, p<0.05\right)$, and that corticosterone was essentially absent in ADX mice (regardless of swim history) (effect of ADX: $F_{(1,20)}=262.50, p<0.01$ ) (Fig. $6 B$ ).

Together, these results suggest that corticosterone is necessary for the repeated swim-induced deficit in hippocampal 5-HT clearance. Furthermore, they lend further support to our hypothesis that this deficit is driven by loss of function of OCT3 and not 
other transporters, such as the corticosterone-insensitive plasma membrane monoamine transporter (PMAT).

\section{Discussion}

Repeated HPA axis activation slows hippocampal 5-HT clearance in vivo via a SERT-independent mechanism

A consistent finding in the literature is that activation of the HPA axis is followed by an elevation in ECF 5-HT in limbic brain regions, including hippocampus (Wilkinson et al., 1996; Amat et al., 1998; Linthorst et al., 2002; Hajós-Korcsok et al., 2003; Beekman et al., 2005). Using repeated swim to activate the HPA axis, the major finding of the present study is that inhibition of 5-HT clearance from ECF is one mechanism through which this occurs. However, we found that the decrease in 5-HT clearance rate following repeated swim was not a consequence of impaired function or expression of the high-affinity uptake mechanism for 5-HT, the SERT, a finding consistent with reports that other HPA axis activators, including repeated restraint (Watanabe et al., 1993), fox odor exposure (Dias Soares et al., 2003), corticosterone ingestion (Fernandez et al., 2001), 3,4-methylenedioxymethamphetamine administration (Williams et al., 2005), and exercise (Chen et al., 2008), fail to alter SERT expression or $\left[{ }^{3} \mathrm{H}\right] 5-\mathrm{HT}$ uptake in in vitro preparations from various brain regions, including hippocampus.

An important observation is that 5-HT clearance was most robustly impaired at concentrations where we have previously shown in hippocampus (using in vivo chronoamperometry) that SERT is less likely to dominate 5-HT uptake, but where lowaffinity-high-capacity transporters for 5-HT, such as OCT3, are known to come into play (Daws, 2009). Indeed, at SERTpredominating concentrations, our in vivo studies revealed no effect of repeated swim on hippocampal 5-HT clearance rate and no effect on the ability of the SERT blocker FVX to inhibit 5-HT clearance. Moreover, the effect of repeated swim to reduce 5-HT clearance (at non-SERT-predominating concentrations) was maintained in SERT KO mice, ruling out SERT as a mechanism and strongly implicating the involvement of another transporter capable of 5-HT uptake. A particularly salient transporter in this regard is the corticosterone-sensitive OCT3. Our subsequent experiments interrogated its potential role in repeated swiminduced impairment of 5-HT clearance.

\section{Repeated HPA axis activation decreases the expression and function of the corticosterone-sensitive OCT3}

A role for OCT3 in regulating 5-HT neurotransmission has only recently been recognized. Some of the first studies by Feng et al. (2005) showed that infusion of the OCT3 blocker D-22 into the hypothalamus of rats increased ECF 5-HT levels more so than an equivalent dose of an SSRI. These findings suggest that ECF 5-HT levels in this brain region under baseline conditions are sufficiently high to recruit OCT3-mediated 5-HT uptake. Feng et al. $(2009,2010)$ went on to show that infusion of corticosterone, an OCT3 antagonist, potentiated the elevation in ECF 5-HT after administration of D-fenfluramine, a 5-HT-releasing agent (Feng et al., 2009), and more recently that mild restraint potentiated the increase in 5-HT following infusion of D-22 into the hypothalamus (Feng et al., 2010). Together, these studies suggest that corticosterone released in response to HPA activation may indeed produce increases in ECF 5-HT by blocking 5-HT clearance via OCT3.

Consistent with this idea, we found that repeated HPA activation, by means of repeated swim, led to decreased expression and function of OCT3 in hippocampus. It is known that repeated blockade of SERT or NET with selective antagonists leads to decreased expression and function of these transporters (Weinshenker et al., 2002; Hirano et al., 2005). Our data are in keeping with repeated blockade of OCT3 by corticosterone, producing analogous effects on OCT3 expression and function. Reduced OCT3 protein was associated with a decrease in the clearance rate of histamine, a substrate for OCT3 but not SERT. Moreover, there was a blunted ability of intrahippocampally applied corticosterone to inhibit 5-HT clearance in mice exposed to repeated swim. Perhaps the most compelling evidence for a role of the corticosterone-sensitive OCT3 in mediating the effect of repeated swim to slow 5-HT clearance was the finding that this effect was lost in ADX mice, devoid of endogenous corticosterone. Certainly other biological signaling molecules, such as mineralocorticoids and androgens, that are likely reduced or eliminated after ADX cannot be ruled out. However, the high affinity of OCT3 for corticosterone and our results showing inhibition of 5-HT clearance by exogenous application of corticosterone (Fig. 5) make corticosterone a likely candidate.

Of course there are many other transporters capable of 5-HT uptake. For example, OCT1, OCT2, PMAT, NET, and dopamine transporter (DAT) are capable of clearing 5-HT with low affinity/ high capacity (Engel et al., 2004) (for review, see Koepsell et al., 2007; Zhou et al., 2007; Daws, 2009). However, we believe that their contributions to the results of the present study are minimal, if any, for several reasons. Primary among them are our findings measuring histamine clearance in hippocampus. Histamine is a substrate for OCT3 and not other biogenic amine transporters, including SERT, NET, and DAT (Schneider et al., 2005; Gasser et al., 2006). OCT1 and OCT2 transport histamine with very low efficiency, if at all (Gründemann et al., 1999; Koepsell et al., 2007). In addition, OCT2 and DAT are sparsely expressed in hippocampus (Javitch et al., 1985; Gorboulev et al., 1997; Alnouti et al., 2006; Koepsell et al., 2007). Likewise, although PMAT is highly expressed in hippocampus it has relatively low histamine transport efficiency (Engel et al., 2004; Gasser et al., 2006). A key difference between OCT3 and PMAT, that is particularly salient in the context of the current study, is that corticosterone acts as an antagonist of OCT3 but not PMAT (Engel et al., 2004; Gasser et al., 2006; Koepsell et al., 2007). Corticosterone is also 100-fold more selective for OCT3 than OCT1 or OCT2 (Hayer-Zillgen et al., 2002). Together, our data point to two likely mechanisms by which repeated swim impairs 5-HT clearance: first, via the acute actions of corticosterone to block OCT3 mediated 5-HT clearance; and second, via the effect of chronic OCT3 blockade by corticosterone (produced by repeated swim) to decrease OCT3 expression and function. One other mechanism that cannot be discounted is 5-HT competing with itself for uptake by OCT3. For example, as a result of OCT3 downregulation and persistently higher levels of corticosterone in mice exposed to repeated swim, basal levels of ECF 5-HT might be predicted to be higher than those in control mice. A higher ambient level of ECF 5-HT could potentially contribute to the slower clearance rate of exogenously applied 5-HT in mice exposed to repeated swim.

\section{Repeated swim does not affect the behavioral response to SERT and NET blockers in the tail suspension test}

The ability of the SERT-selective blockers FLX and FVX, and the NET-selective blocker DMI to decrease immobility time in the TST was not diminished. This provides a behavioral readout in support of our contention that changes in neither SERT nor NET underlie the effect of repeated swim to slow 5-HT clearance from extracellular fluid in brain. We also observed that immobility 
time in saline-injected mice exposed to repeated swim was modestly, but significantly less than in saline-injected unswum mice. Clearly, more comprehensive behavioral analyses are required before the significance of this observation can be clarified. However, it is a finding supported by literature showing that, contingent upon dose and duration of treatment, exogenously applied corticosterone can reduce immobility time (Stone and Lin, 2008; Zhao et al., 2009). Similarly, environment enrichment (another activator of the HPA axis) that leads to similar increases in plasma corticosterone in mice, as reported here, also led to decreased immobility time in the TST (Xu et al., 2009). The effect of environmental enrichment to reduce immobility time was prevented by $\operatorname{ADX}$ (Xu et al., 2009). There are also reports that elevated endogenous corticosterone is sometimes associated with antidepressant- and anxiolytic-like effects in rats and C57BL/6J mice (Swiergiel et al., 2008; Mozhui et al., 2010).

While further studies are needed, particularly in light of the limitations of the TST and FST as assays for "depression" (Cryan and Holmes, 2005), these data provide important behavioral parallels to our neurochemical results, supporting lack of involvement of SERT and NET in mediating reduced 5-HT clearance after repeated swim.

\section{Implications}

Our data show that repeated swim leads to impaired 5-HT clearance via a corticosterone-sensitive transporter, most likely OCT3. Repeated swim caused a modest, but persistent elevation in plasma corticosterone, and corticosterone is a potent blocker of OCT3. Thus, consistent with our findings that the OCT3 blocker D-22 produces antidepressant-like effects in mice with elevated extracellular 5-HT (Baganz et al., 2008) and those of others (Kitaichi et al., 2005), the current data support the idea that modest elevations in plasma corticosterone may act in the same way to produce antidepressant-like effects. Clearly, corticosterone itself is not a viable candidate for the treatment of depression because of its many and varied actions at other receptors and clear prodepressant effects under many conditions (for review, see McEwen, 2008). However, our data build on growing evidence that OCT3 is an important modulator of brain 5-HT and a promising candidate for the development of novel, OCT3-selective drugs for the treatment of depression and related disorders.

\section{References}

Alnouti Y, Petrick JS, Klaassen CD (2006) Tissue distribution and ontogeny of organic cation transporters in mice. Drug Metab Dispos 34:477-482.

Amat J, Matus-Amat P, Watkins LR, Maier SF (1998) Escapable and inescapable stress differentially and selectively alter extracellular levels of 5-HT in the ventral hippocampus and dorsal periaqueductal gray of the rat. Brain Res 797:12-22.

Andersen J, Taboureau O, Hansen KB, Olsen L, Egebjerg J, Strømgaard K, Kristensen AS (2009) Location of the antidepressant binding site in the serotonin transporter: importance of Ser-438 in recognition of citalopram and tricyclic antidepressants. J Biol Chem 284:10276-10284.

Baganz NL, Horton RE, Calderon AS, Owens WA, Munn JL, Watts LT, Koldzic-Zivanovic N, Jeske NA, Koek W, Toney GM, Daws LC (2008) Organic cation transporter 3: keeping the brake on extracellular serotonin in serotonin transporter deficient mice. Proc Natl Acad Sci U S A 105:18976-18981.

Beekman M, Flachskamm C, Linthorst AC (2005) Effects of exposure to a predator on behaviour and serotonergic neurotransmission in different brain regions of C57bl/6N mice. Eur J Neurosci 21:2825-2836.

Bengel D, Murphy DL, Andrews AM, Wichems CH, Feltner D, Heils A, Mössner R, Westphal H, Lesch KP (1998) Altered brain serotonin (5-HT) homeostasis and locomotor insensitivity to MDMA ("ecstasy") in 5-HT transporter deficient mice. Mol Pharmacol 53:649-655.
Blakely RD, Ramamoorthy S, Schroeter S, Qian Y, Apparsundaram S, Galli A, DeFelice LJ (1998) Regulated phosphorylation and trafficking of antidepressant-sensitive serotonin transporter proteins. Biol Psychiatry 44:169-178.

Boyce-Rustay JM, Wiedholz LM, Millstein RA, Carroll J, Murphy DL, Daws LC, Holmes A (2006) Ethanol-related behaviors in serotonin transporter knockout mice. Alcohol Clin Exp Res 30:1957-1965.

Boyce-Rustay JM, Cameron HA, Holmes A (2007) Chronic swim alters sensitivity to acute behavioral effects of ethanol in mice. Physiol Behav 91:77-86.

Bradford MM (1976) A rapid and sensitive method for the quantitation of microgram quantities of protein utilizing the principle of protein-dyebinding. Anal Biochem 72:248-254.

Brenes JC, Rodríguez O, Fornaguera J (2008) Differential effect of environment enrichment and social isolation on depressive-like behavior, spontaneous activity and serotonin and norepinephrine concentration in prefrontal cortex and ventral striatum. Pharmacol Biochem Behav 89:85-93

Buijs RM, Kalsbeek A, van der Woude TP, van Heerikhuize JJ, Shinn S (1993) Suprachiasmatic nucleus lesion increases corticosterone secretion. Am J Physiol 264:R1186-R1192.

Campbell S, Macqueen G (2004) The role of the hippocampus in the pathophysiology of depression. J Psychiatry Neurosci 29:417-426.

Castro JE (1974) Surgical procedures in small laboratory animals. J Immunol Methods 4:213-216.

Chen HI, Lin LC, Yu L, Liu YF, Kuo YM, Huang AM, Chuang JI, Wu FS, Liao PC, Jen CJ (2008) Treadmill exercise enhances passive avoidance learning in rats: the role of down-regulated serotonin system in the limbic system. Neurobiol Learn Mem 89:489-496.

Chen JJ, Li Z, Pan H, Murphy DL, Tamir H, Koepsell H, Gershon MD (2001) Maintenance of serotonin in the intestinal mucosa and ganglia of mice that lack the high-affinity serotonin transporter: abnormal intestinal motility and the expression of cation transporters. J Neurosci 21:6348-6361.

Cryan JF, Holmes A (2005) The ascent of mouse: advances in modeling human depression and anxiety. Nat Rev Drug Discov 4:775-790.

Davidson C, Ellinwood EH, Douglas SB, Lee TH (2000) Effect of cocaine, nomifensine, GBR 12909 and WIN 35428 on carbon fiber microelectrode sensitivity for voltammetric recording of dopamine. J Neurosci Methods 101:75-83.

Daws LC (2009) Unfaithful neurotransmitter transporters: Implications for the treatment of psychiatric disorders. Pharmacol Ther 121:89-99.

Daws LC, Toney GM (2007) Voltammetric methods to study kinetics and mechanisms for serotonin clearance in vivo. In: Electrochemical methods in neuroscience, for methods and new frontiers in neuroscience (Michael AC, Simon SA, Nicolelis MAL, eds), pp 63-81. Boca Raton, FL: CRC.

Daws LC, Montañez S, Owens WA, Gould GG, Frazer A, Toney GM, Gerhardt GA (2005) Transport mechanisms governing serotonin clearance in vivo revealed by high-speed chronoamperometry. J Neurosci Methods 143:49-62.

Daws LC, Montañez S, Munn JL, Owens WA, Baganz NL, Boyce-Rustay JM, Millstein RA, Wiedholz LM, Murphy DL, Holmes A (2006) Ethanol inhibits clearance of brain serotonin by a serotonin transporterindependent mechanism. J Neurosci 26:6431-6438.

de Montigny C, Chaput Y, Blier P (1990) Modification of serotonin neuron properties by long-term treatment with serotonin reuptake blockers. J Clin Psychiatry 51 [Suppl B]:4-8.

Dias Soares D, Fernandez F, Aguerre S, Foury A, Mormède P, Chaouloff F (2003) Fox odour affects corticosterone release but not hippocampal serotonin reuptake and open field behavior in rats. Brain Res 961:166-170

Engel K, Zhou M, Wang J (2004) Identification and characterization of a novel monoamine transporter in the human brain. J Biol Chem 279:50042-50049.

Feng N, Mo B, Johnson PL, Orchinik M, Lowry CA, Renner KJ (2005) Local inhibition of organic cation transporters increases extracellular serotonin in the medial hypothalamus. Brain Res 1063:69-76.

Feng N, Telefont M, Kelly KJ, Orchinik M, Forster GL, Renner KJ, Lowry CA (2009) Local perfusion of corticosterone in the rat medial hypothalamus potentiates D-fenfluramine-induced elevations of extracellular 5-HT concentrations. Horm Behav 56:149-157.

Feng N, Lowry CA, Lukkes JL, Orchinik M, Forster GL, Renner KJ (2010) Organic cation transporter inhibition increases medial hypothalamic se- 
rotonin under basal conditions and during mild restraint. Brain Res 1326:105-113.

Fernandez F, Coomans V, Mormede P, Chaouloff F (2001) Effects of corticosterone ingestion on hippocampal $[(3) \mathrm{H}]$ serotonin reuptake in inbred rat strains. Endocr Regul 35:119-126.

Franklin KBJ, Paxinos G (1997) The mouse brain in stereotaxic coordinates. Sydney, Australia: Academic.

Gasser PJ, Lowry CA, Orchinik M (2006) Corticosterone-sensitive monoamine transport in the rat dorsomedial hypothalamus: potential role for organic cation transporter 3 in stress-induced modulation of monoaminergic neurotransmission. J Neurosci 26:8758-8766.

Gasser PJ, Orchinik M, Raju I, Lowry CA (2009) Distribution of organic cation transporter 3, a corticosterone-sensitive monoamine transporter, in the rat brain. J Comp Neurol 512:529-555.

Gerhardt GA (1995) Rapid chronocoulometric meausurements of norepinephrine overflow and clearance in CNS tissues. In: Neuromethods: voltammetric methods in brain systems, Vol 27 (Boulton AA, Baker GB, Adams RN, eds), pp 117-150. Totowa, NJ: Humana.

Gerhardt GA, Palmer MR (1987) Characterization of the techniques of pressure ejection and microiontophoresis using in vivo electrochemistry. J Neurosci Methods 22:147-159.

Gomez-Merino D, Béquet F, Berthelot M, Chennaoui M, Guezennec CY (2001) Site-dependent effects of an acute intensive exercise on extracellular 5-HT and 5-HIAA levels in rat brain. Neurosci Lett 301:143-146.

Gorboulev V, Ulzheimer JC, Akhoundova A, Ulzheimer-Teuber I, Karbach U, Quester S, Baumann C, Lang F, Busch AE, Koepsell H (1997) Cloning and characterization of two human polyspecific organic cation transporters. DNA Cell Biol 16:871-881.

Gründemann D, Schechinger B, Rappold GA, Schömig E (1998) Molecular identification of the corticosterone-sensitive extraneuronal catecholamine transporter. Nat Neurosci 1:349-351.

Gründemann D, Liebich G, Kiefer N, Köster S, Schömig E (1999) Selective substrates for non-neuronal monoamine transporters. Mol Pharmacol 56:1-10.

Hajós-Korcsok E, Robinson DD, Yu JH, Fitch CS, Walker E, Merchant KM (2003) Rapid habituation of hippocampal serotonin and norepinephrine release and anxiety-related behaviors, but not plasma corticosterone levels, to repeated footshock stress in rats. Pharmacol Biochem Behav 74:609-616.

Hayer-Zillgen M, Brüss M, Bönisch H (2002) Expression and pharmacological profile of the human organic cation transporters hOCT1, hOCT2 and hOCT3. Br J Pharmacol 136:829-836.

Hensler JG, Ferry RC, Labow DM, Kovachich GB, Frazer A (1994) Quantitative autoradiography of the serotonin transporter to assess the distribution of serotonergic projections from the dorsal raphe nucleus. Synapse 17:1-15.

Hirano K, Seki T, Sakai N, Kato Y, Hashimoto H, Uchida S, Yamada S (2005) Effects of continuous administration of paroxetine on ligand binding site and expression of serotonin transporter protein in mouse brain. Brain Res 1053:154-161.

Holmes A, Wellman CL (2009) Stress-induced prefrontal reorganization and executive dysfunction in rodents. Neurosci Biobehav Rev 33:773-783.

Jahng JW, Kim JG, Kim HJ, Kim BT, Kang DW, Lee JH (2007) Chronic food restriction in young rats results in depression- and anxiety-like behaviors with decreased expression of serotonin reuptake transporter. Brain Res 1150:100-107.

Javitch JA, Strittmatter SM, Snyder SH (1985) Differential visualization of dopamine and norepinephrine uptake sites in rat brain using $\left[{ }^{3} \mathrm{H}\right]$ mazindol autoradiography. J Neurosci 5:1513-1521.

Kitaichi K, Fukuda M, Nakayama H, Aoyama N, Ito Y, Fujimoto Y, Takagi K, Takagi K, Hasegawa T (2005) Behavioral changes following antisense oligonucleotide-induced reduction of organic cation transporter-3 in mice. Neurosci Lett 382:195-200.

Koepsell H, Lips K, Volk C (2007) Polyspecific organic cation transporters: structure, function, physiological roles, and biopharmaceutical implications. Pharm Res 24:1227-1251.

Kovachich GB, Aronson CE, Brunswick DJ, Frazer A (1988) Quantitative autoradiography of serotonin uptake sites in rat brain using $\left[{ }^{3} \mathrm{H}\right]-$ cyanoimpramine. Brain Res 454:78-88.

La Fleur SE, Kalsbeek A, Wortel J, Buijs RM (1999) A suprachiasmatic nu- cleus generated rhythm in basal glucose concentrations. J Neuroendocrinol 11:643-652.

Lanfumey L, Mongeau R, Cohen-Salmon C, Hamon M (2008) Corticosteroid-serotonin interactions in the neurobiological mechanisms of stress-related disorders. Neurosci Biobehav Rev 32:1174-1184.

Leonardo ED, Hen R (2006) Genetics of affective and anxiety disorder. Annu Rev Psychol 57:117-137.

Li JD, Hu WP, Boehmer L, Cheng MY, Lee AG, Jilek A, Siegel JM, Zhou QY (2006) Attenuated circadian rhythms in mice lacking the prokineticin 2 gene. J Neurosci 26:11615-11623.

Li Q, Wichems C, Heils A, Van De Kar LD, Lesch KP, Murphy DL (1999) Reduction of 5-hydroxytryptamine (5-HT) (1A)-mediated temperature and neuroendocrine responses and 5-HT(1A) binding sites in 5-HT transporter knockout mice. J Pharmacol Exp Ther 291:999-1007.

Linthorst AC, Peñalva RG, Flachskamm C, Holsboer F, Reul JM (2002) Forced swim stress activates rat hippocampal serotonergic neurotransmission involving a corticotropin-releasing hormone receptor-dependent mechanism. Eur J Neurosci 16:2441-2452.

Maines LW, Keck BJ, Smith JE, Lakoski JM (1999) Corticosterone regulation of serotonin transporter and 5-HT1A receptor expression in the aging brain. Synapse 32:58-66.

McEwen BS (1999) Stress and hippocampal plasticity. Annu Rev Neurosci 22:105-122.

McEwen BS (2008) Central effects of stress hormones in health and disease: Understanding the protective and damaging effects of stress and stress mediators. Eur J Pharmacol 583:174-185.

McKittrick CR, Magariños AM, Blanchard DC, Blanchard RJ, McEwen BS, Sakai RR (2000) Chronic social stress reduces dendritic arbors in CA3 of hippocampus and decreases binding to serotonin transporter sites. Synapse 36:85-94.

Meeusen R, De Meirleir K (1995) Exercise and brain neurotransmission. Sports Med 20:160-188.

Montañez S, Owens WA, Gould GG, Murphy DL, Daws LC (2003) Exaggerated effects of fluvoxamine in heterozygote serotonin transporter knockout mice. J Neurochem 86:210-219.

Moore RY, Eichler VB (1972) Loss of a circadian adrenal corticosterone rhythm following suprachiasmatic lesions in the rat. Brain Res 42:201-206.

Mozhui K, Karlsson RM, Kash TL, Ihne J, Norcross M, Patel S, Farrell MR, Hill EE, Graybeal C, Martin KP, Camp M, Fitzgerald PJ, Ciobanu DC, Sprengel R, Mishina M, Wellman CL, Winder DG, Williams RW, Holmes A (2010) Strain differences in stress responsivity are associated with divergent amygdala gene expression and glutamate-mediated neuronal excitability. J Neurosci 30:5357-5367.

Murphy DL, Fox MA, Timpano KR, Moya PR, Ren-Patterson R, Andrews AM, Holmes A, Lesch KP, Wendland JR (2008) How the serotonin story is being rewritten by new gene-based discoveries principally related to SLC6A4, the serotonin transporter gene, which functions to influence all cellular serotonin systems. Neuropharmacology 55:932-960.

Perez XA, Bianco LE, Andrews AM (2006) Filtration disrupts synaptosomes during radiochemical analysis of serotonin uptake: comparison with chronoamperometry in SERT knockout mice. J Neurosci Methods 154:245-255.

Schneider E, Machavoine F, Pléau JM, Bertron AF, Thurmond RL, Ohtsu H, Watanabe T, Schinkel AH, Dy M (2005) Organic cation transporter 3 modulates murine basophil functions by controlling intracellular histamine levels. J Exp Med 202:387-393.

Steru L, Chermat R, Thierry B, Simon P (1985) The tail suspension test: a new method for screening antidepressants in mice. Psychopharmacology 85:367-370.

Stone EA, Lin Y (2008) An anti-immobility effect of exogenous corticosterone in mice. Eur J Pharmacol 580:135-142.

Swiergiel AH, Leskov IL, Dunn AJ (2008) Effects of chronic and acute stressors and CRF on depression-like behavior in mice. Behav Brain Res 186:32-40.

Watanabe Y, Gould E, McEwen BS (1992) Stress induces atrophy of apical dendrites of hippocampal CA3 pyramidal neurons. Brain Res 588:341-345.

Watanabe Y, Sakai RR, McEwen BS, Mendelson S (1993) Stress and antidepressant effects on hippocampal and cortical 5-HT1A and 5-HT2 receptors and transport sites for serotonin. Brain Res 615:87-94.

Weinshenker D, White SS, Javors MA, Palmiter RD, Szot P (2002) Regula- 
tion of norepinephrine transporter abundance by catecholamines and desipramine in vivo. Brain Res 946:239-246.

Wilkinson LS, Humby T, Killcross S, Robbins TW, Everitt BJ (1996) Dissociations in hippocampal 5-hydroxytryptamine release in the rat following Pavlovian aversive conditioning to discrete and contextual stimuli. Eur J Neurosci 8:1479-1487.

Williams JM, Owens WA, Turner GH, Saunders C, Dipace C, Blakely RD, France CP, Gore JC, Daws LC, Avison MJ, Galli A (2007) Hypoinsulinemia regulates amphetamine-induced reverse transport of dopamine. PLoS Biol 5:e274.

Williams MT, Schaefer TL, Ehrman LA, Able JA, Gudelsky GA, Sah R, Vorhees CV (2005) 3,4-Methylenedioxymethamphetamine administration on postnatal day 11 in rats increases pituitary-adrenal output and reduces striatal and hippocampal serotonin without altering SERT activity. Brain Res 1039:97-107.
Xu Z, Hou B, Zhang Y, Gao Y, Wu Y, Zhao S, Zhang C (2009) Antidepressive behaviors induced by enriched environment might be modulated by glucocorticoid levels. Eur Neuropsychopharmacol 19:868-875.

Yoshitake T, Wang FH, Kuteeva E, Holmberg K, Yamaguchi M, Crawley JN, Steiner R, Bartfai T, Ogren SO, Hökfelt T, Kehr J (2004) Enhanced hippocampal noradrenaline and serotonin release in galanin-overexpressing mice after repeated forced swimming test. Proc Natl Acad Sci U S A 101:354-359.

Zhao Y, Xie W, Dai J, Wang Z, Huang Y (2009) The varying effects of shortterm and long-term corticosterone injections on depression-like behavior in mice. Brain Res 1261:82-90.

Zhou M, Engel K, Wang J (2007) Evidence for significant contribution of a newly identified monoamine transporter (PMAT) to serotonin uptake in the human brain. Biochem Pharmacol 73:147-154. 